\title{
PEMANFAATAN SOFTWARE PEMBUKUAN AKUNTANSI SEBAGAI SOLUSI ATAS SISTEM PEMBUKUAN MANUAL PADA UMKM
}

\author{
Oleh: Xena Legina ${ }^{1}$, Irma Paramita Sofia ${ }^{2}$ \\ xena.legina@student.upj.ac.id ${ }^{1}$, irma.paramita@upj.ac.id $^{2}$ \\ (Program Studi Akuntansi, FHB Universitas Pembangunan Jaya)
}

\begin{abstract}
Abstrak-Pembukuan merupakan hal yang harus diterapkan oleh para pelaku UMKM. Pembukuan dapat dilakukan baik secara manual maupun komputerisasi. Berdasarkan hasil penyebaran kuesioner, delapan dari sepuluh pelaku UMKM di kawasan Ceger Raya masih menerapkan sistem pembukuan manual. Di mana saat menerapkan sistem tersebut, masih terdapat beberapa permasalahan yang harus dihadapi. Oleh sebab itu, penelitian ini bertujuan untuk menganalisis permasalahan apa saja yang seringkali dihadapi oleh para pelaku UMKM selama menerapkan sistem pembukuan secara manual serta memberikan solusi atas permasalahan tersebut. Metode penelitian yang digunakan adalah deskriptif kualitatif berdasarkan sumber data primer dan data sekunder yang telah diperoleh dengan melakukan penelitian lapangan. Hasil dari penelitian ini adalah memberikan penjelasan mengenai pengarsipan dokumen keuangan yang baik, pencatatan mengenai laporan keuangan, serta panduan menggunakan software pembukuan akuntansi yang dapat membantu para pelaku UMKM dalam mengelola kegiatan usaha yang dijalankan.
\end{abstract}

Kata Kunci: UMKM, Software, Pembukuan, Akuntansi.

Abstract-Book keeping is something that must be applied by MSME performers. Book keeping can be done either manually or computerized. Based on the results of distributing questionnaires, eight out of ten MSME players in the Ceger Raya area still apply a manual book keeping sistem. Where when implementing the sistem, there are still several problems that must be faced. Therefore, this study aims to analyze what problems are often faced by MSME performers while implementing a manual book keeping sistem and provide solutions to these problems. The research method used is descriptive qualitative based on primary data and secondary data sources that have been obtained by conducting field research. The results of this study are to provide an explanation of good financial document archiving, recording of financial reports, and guidelines for using accounting book keeping software that can help MSMEs to manage their business activities.

Keywords: MSME, Software, Book Keeping, Accounting.

\section{PENDAHULUAN}

Revolusi industri 4.0 saat ini menjadi tantangan yang harus dihadapi oleh berbagai sektor industri terutama UMKM. Di mana dengan adanya perkembangan 
teknologi baru, memungkinkan manusia untuk lebih mengoptimalkan fungsi otak dibandingkan fisik. Hal tersebut dikarenakan hadirnya revolusi industri 4.0 merubah sistem kerja manual menjadi sistem kerja berbasis teknologi, seperti Internet of Things (IoT), Big Data, Artificial Intelligence (AI), Cloud Computing, dan Addictive Manufacturing (aptika.kominfo.go.id). Oleh sebab itu, teknologi menjadi hal vital yang dibutuhkan oleh para pelaku industri demi efisiensi waktu, tenaga kerja, dan biaya. Tentunya teknologi tersebut juga akan berdampak pada sistem dan mekanisme aliran produksi dan manajemen di seluruh sektor industri.

Sebagai bagian dari pelaku sektor industri, UMKM memiliki peran dan kontribusi yang besar terhadap produksi nasional, penyerapan tenaga kerja serta terhadap perekonomian nasional. Dilansir dalam depkop.go.id mengenai berita "Kemkop dan UKM Targetkan Peningkatan Kontribusi UMKM Untuk PDB" sebagaimana dikatakan oleh Menteri Koperasi dan UKM, yaitu Teten Masduki bahwa penargetan pada akhir 2020 kontribusi UMKM terhadap ekspor meningkat menjadi $18 \%$ dari sebelumnya $14 \%$, terhadap PDB nasional meningkat menjadi $61 \%$ dan kewirausahaan menjadi sebesar $3,55 \%$.
Besarnya kontribusi UMKM terhadap PDB menuntut para pelaku UMKM untuk dapat beradaptasi dengan perkembangan teknologi yang ada agar dapat bertahan dan bersaing di era revolusi industri 4.0. Namun kurang tanggapnya para pelaku UMKM terhadap perkembangan teknologi masih menjadi persoalan yang harus ditanggapi secara serius. Terlebih, adanya data terbaru yang dilansir dari ekonomi.bisnis.com dengan judul "BukuKas, Solusi Pembukuan Keuangan Digital UMKM" di mana Kementerian Komunikasi dan Informatika menyatakan bahwa dari total sekitar 60 juta UMKM yang ada di Indonesia, baru sekitar 9.4 juta UMKM yang sudah go online. Dalam hal ini yang dimaksud dengan go online adalah pemanfaatan teknologi sebagai sarana perluasan usaha yang dijalankan sehingga para pelaku UMKM dapat dengan mudah melakukan berbagai hal, di antaranya seperti penelitian, pengembangan, pemasaran, penjualan, serta pendistribusian produk atau jasa yang ditawarkan.

Selain sebagai sarana perluasan usaha, perkembangan teknologi juga dapat membantu para pelaku UMKM untuk dapat memanfaatkan software pembukuan sebagai pengganti sistem pembukuan manual. Dalam penelitian ini, sistem pembukuan manual sebenarnya bukan masalah yang besar bagi para pelaku UMKM, tetapi yang menjadi masalah yaitu 
apabila seluruh transaksi yang terjadi diolah secara manual dengan mengandalkan kertas untuk pengarsipan data suatu usaha. Di mana hal tersebut dapat menimbulkan adanya risiko kehilangan data akibat penyimpanan yang kurang baik. Hal tersebut tentu akan menghambat seluruh kegiatan operasional UMKM, karena seluruh transaksi harus dianalisis, diolah, dan dicatat satu per satu sesuai dengan tahapan-tahapan yang harus dilakukan secara manual. Proses pengolahan data tersebut sangat tidak efektif dan efisien baik dari segi waktu maupun keakuratan data terkait dengan laporan keuangan yang dihasilkan.

Laporan keuangan yang baik dan berkualitas adalah laporan keuangan yang mampu menyajikan informasi mengenai posisi keuangan suatu usaha yang dijalankan sehingga dapat dijadikan pedoman dalam pengambilan keputusan, baik oleh pihak internal maupun eksternal. Menyajikan laporan keuangan menjadi masalah tersendiri bagi para pelaku UMKM, terlebih bagi mereka yang mungkin masih belum memiliki kemampuan dalam melakukan pembukuan baik secara manual maupun sistem. Hal tersebut perlu ditanggapi secara serius, mengingat fakta bahwa laporan keuangan menjadi alat ukur kesehatan dan keberlanjutan usaha yang dijalankan.
Berdasarkan hal tersebut di atas, maka sistem pembukuan manual kurang efektif untuk diterapkan oleh para pelaku UMKM. Hal tersebut dikarenakan sistem pembukuan manual dapat menimbulkan kemungkinan terjadinya berbagai kesalahan, seperti kesalahan matematis saat berhitung, kesalahan pencatatan dan penyesuaian, serta kelupaan dalam mencatat transaksi yang terjadi. Berdasarkan permasalahan tersebut, maka peneliti memberikan solusi kepada para pelaku UMKM agar beralih dari sistem pembukuan manual menjadi sistem pembukuan komputerisasi dengan memanfaatkan software pembukuan gratis yang dapat digunakan dengan mudah oleh para pelaku UMKM, yaitu BukuKas. Dengan memanfaatkan software pembukuan gratis, maka para pelaku UMKM akan memperoleh lebih banyak keuntungan, baik dari segi keamanan, keakuratan data, waktu (lebih efisien), serta kemudahan dalam mengakses data.

Adapun definisi Usaha Mikro, Kecil, dan Menengah (UMKM) menurut Badan Pusat Statistik (BPS) berdasarkan kuantitas tenaga kerja. Di mana usaha kecil merupakan entitas usaha yang memiliki jumlah tenaga kerja sebanyak 5 s.d. 19 orang, sedangkan usaha menengah memiliki jumlah tenaga kerja sebanyak $20 \quad$ s.d. 99 orang (Juliprijanto et al, 2017). Kemudian, menurut Bab IV Pasal 6 Undang- 
Undang Republik Indonesia Nomor 20 Tahun 2008 UMKM memiliki beberapa kriteria, yaitu usaha mikro dengan kekayaan bersih maksimal Rp 50 juta dan omset maksimal Rp 300 juta. Selanjutnya, usaha kecil dengan kekayaan bersih lebih dari Rp 50 juta s.d. Rp 500 juta dan omset lebih dari Rp 300 juta s.d. Rp 2,5 miliar. Sedangkan usaha menengah dengan kekayaan bersih lebih dari Rp 500 juta s.d. Rp 10 miliar dan omset lebih dari Rp 2.5 miliar s.d. Rp 50 miliar (ojk.go.id).

Krismiaji

mendefinisikan sistem informasi akuntansi sebagai sebuah sistem yang memproses data dan transaksi dengan tujuan menghasilkan informasi yang berguna baik dalam merencanakan, mengendalikan, dan mengoperasikan bisnis. Selanjutnya, untuk definisi sistem sendiri menurut Mulyadi (2010) merupakan sekelompok unsur yang erat berhubungan satu dengan lainnya yang saling berkaitan, dan tidak terpisahkan yang juga mempunyai fungsi yang sama untuk mencapai sebuah tujuan. Sedangkan definisi akuntansi menurut Pangerapan (2013) merupakan suatu proses mengidentifikasikan, mencatat dan melaporkan informasi ekonomi yang terjadi dalam suatu kegiatan usaha, untuk digunakan sebagai pedoman dalam pengambilan keputusan manajemen.

Kemudian berdasarkan

Undang-Undang Republik Indonesia
Nomor 28 Tahun 2007 Pasal 1 (29), dapat diketahui bahwa pembukuan merupakan suatu proses pencatatan yang dilakukan secara teratur dengan tujuan untuk mengumpulkan data dan informasi keuangan yang meliputi harta, kewajiban, modal, penghasilan dan biaya, serta jumlah harga perolehan dan penyerahan barang atau jasa, yang ditutup dengan menyusun laporan keuangan berupa neraca, dan laporan laba rugi untuk periode Tahun Pajak tersebut.

Pada penelitian sebelumnya yang dilakukan oleh Rahardja et al (2018) mengenai Penerapan Software Akuntansi Online Sebagai Penunjang Pencatatan Laporan Keuangan dapat diketahui bahwa salah satu software akuntansi, yaitu Jurnal dapat mempermudah akuntan dalam menginput dan mengimport seluruh data transaksi ke dalam sistem sehingga waktu pengerjaan lebih efisien. Penerapan software akuntansi Jurnal juga dinilai dapat mengurangi penggunaan kertas untuk membuat laporan keuangan apabila terjadi kesalahan. Hal tersebut dikarenakan akuntan hanya perlu memperbaiki data yang salah, dan kemudian data akan dihitung kembali secara otomatis untuk dijadikan laporan keuangan. Selain itu, kerahasiaan data dapat dipastikan tersimpan dengan baik karena adanya pengamanan data yang digunakan oleh software akuntansi Jurnal sangat baik. 
Sedangkan peneliti tertarik untuk menganalisis permasalahan apa saja yang seringkali dihadapi oleh para pelaku UMKM di kawasan Ceger Raya selama menerapkan sistem pembukuan secara manual, serta memberikan solusi atas permasalahan tersebut. Di mana solusi tersebut berupa panduan menggunakan software pembukuan gratis, yaitu BukuKas. BukuKas dapat digunakan dengan mudah oleh para pelaku UMKM kapan pun dan dimana pun karena penggunaannya berbasis mobile. Hal tersebut tentunya dapat menunjang kegiatan usaha yang dijalankan oleh para pelaku UMKM. Penelitian ini bertujuan untuk membantu para pelaku UMKM dalam memanfaatkan software pembukuan, salah satunya seperti BukuKas supaya kegiatan usaha yang dijalankan dapat lebih efektif dan efisien.

\section{METODE PENELITIAN}

Penelitian ini merupakan penelitian deskriptif dengan menggunakan pendekatan kualitatif untuk memberikan ulasan yang telah diperoleh peneliti melalui penyebaran kuesioner dengan responden penelitian. Pendekatan penelitian deskriptif dalam penelitian ini digunakan untuk memberikan penjelasan mengenai fenomena yang terjadi pada para pelaku UMKM terkait dengan diterapkannya sistem pembukuan manual.
Populasi dalam penelitian ini adalah UMKM yang ada di kawasan Ceger Raya. Peneliti mengambil sampel penelitian dengan teknik purposive sampling, yaitu teknik pengambilan sampel berdasarkan pertimbangan-pertimbangan tertentu sesuai dengan tujuan penelitian (Sugiyono, 2010).

Penelitian ini menggunakan jenis data primer yang diperoleh melalui penelitian lapangan. Di mana para pelaku UMKM di kawasan Ceger Raya sebagai responden yang menjadi sumber data primer dalam penelitian ini, di antaranya terdiri dari toko bangunan, toko pompa, toko elektronik, toko obat, toko laundry, toko kue, toko elektrik, bengkel, warung makan, dan tempat fotokopian.

\section{HASIL DAN PEMBAHASAN \\ Hasil}

Penelitian ini dilakukan untuk menganalisis permasalahan yang seringkali dihadapi oleh para pelaku UMKM di kawasan Ceger Raya terkait diterapkannya sistem pembukuan manual serta minat para pelaku UMKM untuk mengubah sistem pembukuan yang diterapkan menjadi sistem pembukuan komputerisasi (software) akuntansi. Sebelum mengkaji permasalahan yang seringkali dihadapi oleh para pelaku UMKM, maka perlu adanya pengkajian mengenai pengetahuan yang dimiliki oleh para pelaku UMKM terkait dengan pembukuan 
dan sistem pembukuan yang diterapkan dalam menjalankan kegiatan usaha yang diperoleh dari hasil diagram data primer berupa kuesioner. Berikut merupakan hasil analisis kuesioner penelitian:

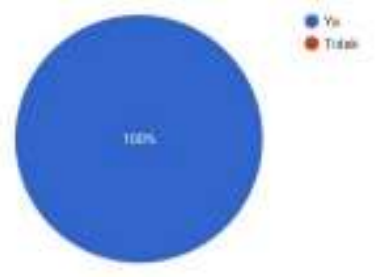

Gambar 1. Diagram terkait pemahaman para pelaku UMKM mengenai pembukuan. (Sumber: Hasil penelitian diolah, 2020)

Berdasarkan gambar diagram di atas, maka dapat diketahui bahwa 10 pelaku UMKM yang menjadi responden dalam penelitian ini telah mengetahui penjelasan mengenai pembukuan.

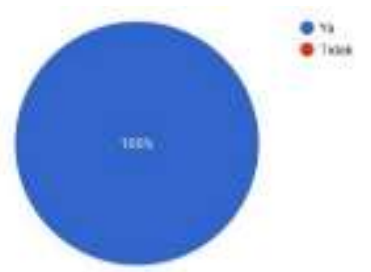

Gambar 2. Diagram terkait apakah para pelaku UMKM telah menerapkan pembukuan atas kegiatan usaha yang dijalankan. (Sumber: Hasil penelitian diolah, 2020)

Berdasarkan gambar diagram di atas, maka dapat diketahui bahwa
10 pelaku UMKM yang menjadi responden dalam penelitian ini telah menerapkan pembukuan atas kegiatan usaha yang dijalankan.

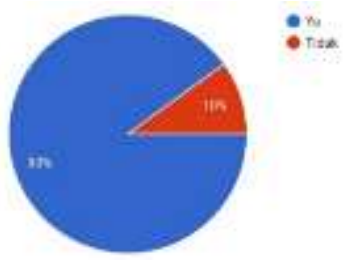

Gambar 3. Diagram terkait apakah para pelaku UMKM telah mengetahui bahwa dengan menerapkan pembukuan maka UMKM dapat meminimalisasi biaya pengeluaran dalam kegiatan usaha yang dijalankan. (Sumber: Hasil penelitian diolah, 2020)

Berdasarkan gambar diagram di atas, maka dapat diketahui bahwa sembilan dari sepuluh (90\%) pelaku UMKM menjawab "Ya" atas pertanyaan yang diajukan. Hal tersebut menunjukkan bahwa mayoritas para pelaku UMKM telah mengetahui bahwa penerapan pembukuan dapat meminimalisasi biaya pengeluaran dalam kegiatan usaha yang dijalankan.

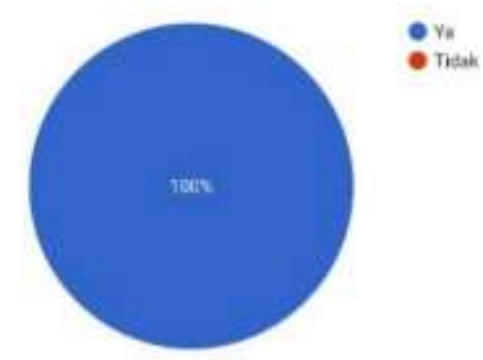

Gambar 4. Diagram terkait apakah para pelaku UMKM telah mengetahui bahwa dengan 
menerapkan pembukuan maka UMKM dapat mengetahui untung atau tidaknya kegiatan usaha yang dijalankan. (Sumber: Hasil penelitian diolah, 2020)

Berdasarkan gambar diagram di atas, maka dapat diketahui bahwa 10 pelaku UMKM telah mengetahui bahwa dengan menerapkan pembukuan maka UMKM dapat mengatahui untung atau tidaknya kegiatan usaha yang dijalankan.

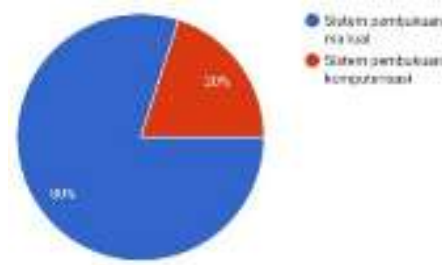

Gambar 5. Diagram terkait sistem pembukuan yang diterapkan oleh para pelaku UMKM

(Sumber: Hasil penelitian

diolah, 2020)

Berdasarkan gambar diagram di atas, maka dapat diketahui bahwa delapan dari sepuluh (80\%) pelaku UMKM masih menerapkan sistem pembukuan manual, dan dua sisanya telah menerapkan sistem pembukuan berbasis komputer (software) akuntansi.

Kemudian pertanyaan terkait permasalahan-permasalahan yang seringkali dihadapi oleh para pelaku UMKM selama menerapkan sistem pembukuan manual, disertai dengan solusi yang diberikan oleh peneliti sebagai penyelesaian dari permasalahan tersebut. Berikut ringkasannya:

Tabel 1. Penemuan Masalah dan Solusi Penelitian

\begin{tabular}{|c|c|}
\hline Permasalahan & Penyelesaian \\
\hline $\begin{array}{l}\text { 1. Lupa menyimpan bukti } \\
\text { transaksi, yaitu dengan } \\
\text { persentase sebesar } 30 \% \text {. }\end{array}$ & $\begin{array}{l}\text { 1. Menyimpan seluruh bukti transaksi } \\
\text { setelah melakukan pencatatan. Dalam } \\
\text { hal ini, peneliti memberikan flowchart } \\
\text { mengenai filing management yang } \\
\text { baik beserta SOP yang berlaku. }\end{array}$ \\
\hline $\begin{array}{l}\text { 2. Kesalahan matematis saat } \\
\text { berhitung, yaitu dengan } \\
\text { persentase sebesar } 40 \% \text {. }\end{array}$ & $\begin{array}{l}\text { 2. Memeriksa kembali untuk } \\
\text { memastikan bahwa perhitungan telah } \\
\text { dilakukan dengan benar, kemudian } \\
\text { jika terdapat kesalahan maka harus } \\
\text { segera diperbaiki. }\end{array}$ \\
\hline $\begin{array}{l}\text { 3. Kesalahan pencatatan dan } \\
\text { penyesuaian, yaitu dengan } \\
\text { persentase sebesar } 50 \% \text {. }\end{array}$ & $\begin{array}{l}\text { 3. Memeriksa dan memastikan bahwa } \\
\text { seluruh pencatatan dan penyesuaian } \\
\text { telah dilakukan dengan baik dan benar } \\
\text { sehingga tidak ada pencatatan yang } \\
\text { terlewat. }\end{array}$ \\
\hline $\begin{array}{l}\text { 4. Selain itu, ada pula yang } \\
\text { menjawab lupa mencatat. }\end{array}$ & $\begin{array}{l}\text { 4. Seluruh transaksi yang terjadi harus } \\
\text { segera dicatat supaya tidak lupa } \\
\text { melakukan pencatatan. }\end{array}$ \\
\hline
\end{tabular}

Sumber: Hasil penelitian diolah, 2020 
Permasalahan - permasalahan dalam tabel di atas menyebabkan kegiatan usaha yang dilakukan para pelaku UMKM menjadi kurang efektif dan efisien sehingga dapat menghambat perkembangan usaha yang dijalankan.

\section{Pembahasan}

Berdasarkan hasil analisis kuesioner di atas, maka peneliti memberikan solusi yang sesuai guna meminimalisasi permasalahanpermasalahan yang terjadi terkait diterapkannya sistem pembukuan manual tersebut, di antaranya:

1. Memberikan penjelasan melalui bagan alir mengenai pengarsipan dokumen keuangan yang baik beserta standar operasional prosedur (SOP) yang harus diterapkan. Hal tersebut dilakukan guna meminimalisasi kesalahan dalam menyimpan bukti transaksi.

2. Memberikan penjelasan melalui bagan alir mengenai pencatatan laporan keuangan sederhana beserta standar operasional prosedur (SOP) yang harus diterapkan. Hal tersebut dilakukan guna membantu para pelaku UMKM dalam mengelola kegiatan usaha yang dijalankan.

3. Memberikan panduan mengenai cara menggunakan software pembukuan akuntansi yaitu BukuKas yang dapat digunakan dengan mudah oleh para pelaku
UMKM guna menunjang kegiatan usaha yang dijalankan.

Hal tersebut dapat menjadi pertimbangan bagi para pelaku UMKM agar beralih dari sistem pembukuan manual menjadi sistem pembukuan komputerisasi. Hal tersebut dikarenakan sistem pembukuan komputerisasi lebih menguntungkan untuk diterapkan oleh para pelaku UMKM, baik dari segi keamanan, keakuratan data, waktu (lebih efisien), serta kemudahan dalam mengakses data.

Terlebih melalui hasil penyebaran kuesioner dapat diketahui bahwa tujuh dari sepuluh atau sebesar $70 \%$ pelaku UMKM berpikir untuk mengubah sistem pembukuan manual menjadi sistem pembukuan berbasis komputer (software) akuntansi. Selain itu, delapan dari sepuluh atau sebesar 80\% pelaku UMKM juga berminat untuk mengikuti pelatihan mengenai pembukuan berbasis komputer (software) akuntansi.

\section{Standar Operasional Prosedur (SOP) Pengarsipan Dokumen Keuangan}

1. Tujuan

Agar seluruh dokumen keuangan terkait transaksi yang terjadi dalam kegiatan usaha dapat tersimpan dengan baik sehingga kegiatan operasional usaha dapat berjalan secara lebih efektif.

2. Pihak Terkait 
- Pihak Internal (Owner).

- Karyawan Bagian Keuangan.

3. Dokumen yang Digunakan

Bukti transaksi, seperti nota, bon, kwitansi, faktur, dan lain sebagainya.

4. Prosedur Pelaksanaan

Saat terjadinya transaksi dan Owner telah menerima pembayaran dari pelanggan, maka Owner yang secara langsung mengelola keuangan usaha segera membuat bukti transaksi rangkap dua, di mana bukti transaksi yang satu akan diberikan kepada pelanggan sedangkan yang lain disimpan oleh Owner sebagai bukti adanya penjualan yang terjadi. Kemudian dilakukanlah pencatatan terkait dengan transaksi yang terjadi, yaitu:

1) Penerimaan kas

Di dalam penerimaan kas terdapat beberapa transaksi, di antaranya penjualan tunai, penerimaan piutang, serta penerimaan lainnya.

2) Pengeluaran kas

Di dalam pengeluaran kas, di antaranya pembayaran utang, pembelian barang dagangan, serta pengeluaran lainnya.

Setelah melakukan pencatatan terkait transaksi yang terjadi tersebut, Owner segera menyimpan atau mengarsipkan bukti transaksi sesuai dengan tanggal terjadinya transaksi ke dalam boks arsip yang telah disediakan. Arsip dilakukan dengan tujuan sebagai berikut:

1. Alat pertanggungjawaban perusahaan atas pelaksanaan dan pengelolaan suatu perusahaan.

2. Agar setiap bidang pekerjaan dalam suatu perusahaan tidak terbebani dengan adanya penyimpanan arsip yang tidak dibutuhkan lagi (Rohman, 2019).

\section{Prosedur Pengarsipan Dokumen Keuangan}

Saat terjadi transaksi dalam kegiatan usaha, maka Owner atau karyawan bagian keuangan segera membuat bukti transaksi yang dirangkap menjadi dua bagian. Di mana bukti transaksi asli akan diberikan kepada pelanggan, dan salinannya disimpan sebagai bukti transaksi internal. Berdasarkan bukti transaksi tersebut, dilakukan pencatatan atas transaksi yang terjadi, yaitu penerimaan kas. Setelah itu, salinan bukti transaksi tersebut disimpan di dalam boks arsip dengan tujuan pengamanan bukti transaksi dari adanya kegiatan usaha tersebut. 


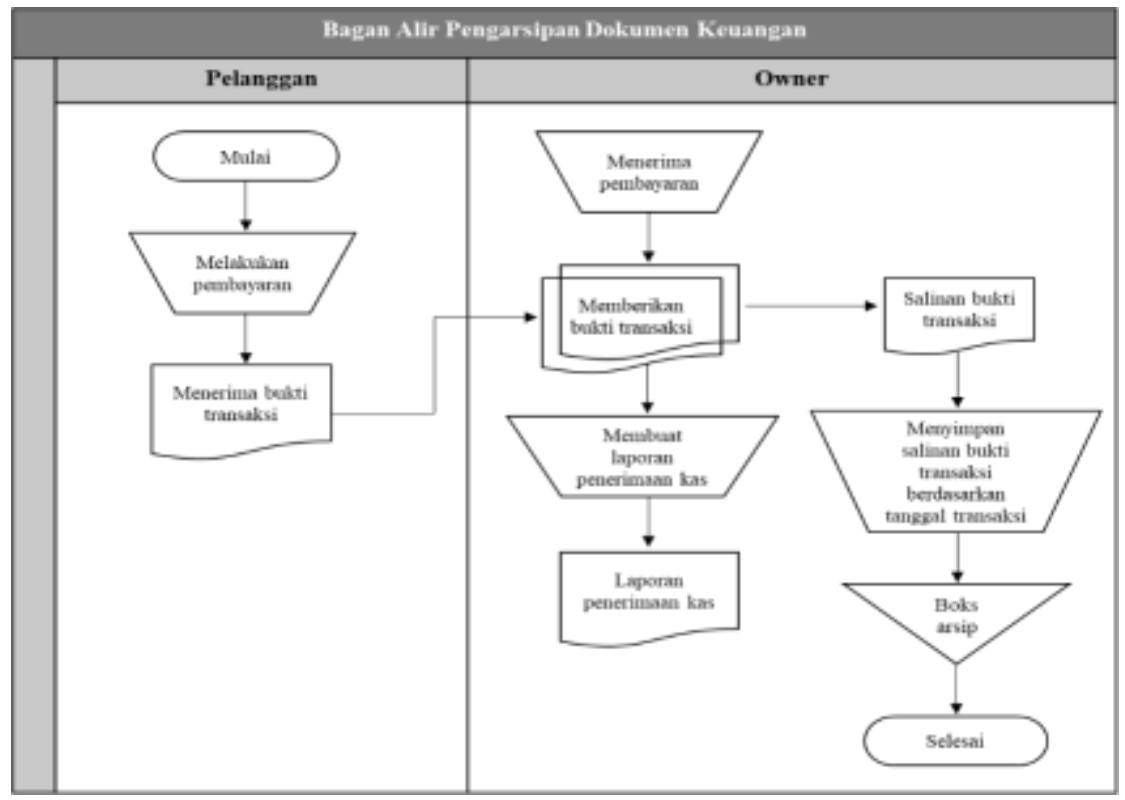

Gambar 6. Bagan Alir Pengarsipan Dokumen Keuangan

(Sumber: Bagan alir diolah oleh peneliti)

\section{Standar Operasional Prosedur (SOP) Pencatatan Laporan}

\section{Keuangan}

1. Tujuan

Agar para pelaku usaha dapat mengetahui untung atau tidaknya usaha yang dijalankan. Selain itu, laporan keuangan juga digunakan oleh pihak-pihak yang berkepentingan dalam hal pengambilan keputusan.

2. Pihak Terkait

- Pihak Internal (Owner).

- Karyawan Bagian Keuangan (Akuntan).

3. Dokumen yang Digunakan

Bukti transaksi, seperti nota, bon, kwitansi, faktur, dan lain sebagainya.

4. Prosedur Pelaksanaan

Saat terjadinya transaksi, baik Owner maupun Akuntan harus melakukan kegiatan pencatatan.
Berdasarkan bukti transaksi yang ada, dibuatlah jurnal yang kemudian dilanjutkan dengan pembuatan buku besar, neraca saldo, jurnal penyesuaian hingga pada akhirnya pembuatan laporan keuangan. Di mana laporan keuangan tersebut harus dibuat sesuai dengan Standar Akuntansi Keuangan Entitas Tanpa Akuntabilitas.

\section{Prosedur Penyusunan Laporan Laba Rugi}

Laporan laba rugi terdiri dari dua komponen, yaitu pendapatan dan beban. Informasi mengenai kedua komponen tersebut dapat dilihat melalui Neraca Saldo Setelah Disesuaikan. Hal pertama yang harus dilakukan adalah memposting seluruh pendapatan dan beban dengan benar. Setelah itu, 
pendapatan dikurangkan dengan beban pokok pendapatan sehingga menghasilkan laba bruto yang kemudian dikurangkan kembali dengan beban usaha sehingga menghasilkan laba usaha. Laba usaha tersebut kemudian dikalkulasi dengan pendapatan dan beban lainnya sehingga menghasilkan laba sebelum pajak. Jika terdapat beban pajak, maka harus dikurangkan sehingga dapat menghasilkan laba bersih.

\section{Prosedur Penyusunan Laporan Perubahan Ekuitas}

Informasi yang diperlukan untuk membuat laporan perubahan ekuitas dapat dilihat melalui Neraca Saldo Setelah Disesuaikan. Hal pertama yang harus dilakukan adalah memposting setoran modal di awal periode berjalan, kemudian memasukkan laba bersih yang telah diperoleh dari laporan laba rugi sebelumnya. Laba bersih tersebut kemudian dikurangkan dengan prive pemilik (jika ada) sehingga dapat diketahui jumlah perubahan modal periode berjalan. Setelah itu, lakukan penjumlahan antara setoran modal di awal periode berjalan dengan jumlah perubahan modal tersebut guna mengetahui saldo modal di akhir periode berjalan.

\section{Prosedur Penyusunan Laporan Posisi Keuangan}

Informasi yang diperlukan untuk membuat laporan posisi keuangan dapat dilihat juga melalui
Neraca Saldo Setelah Disesuaikan. Hal pertama yang harus dilakukan adalah memposting seluruh aset, baik lancar maupun tidak lancar, serta liabilitas dan ekuitas. Di mana saldo ekuitas tersebut tentunya diperoleh dari laporan perubahan ekuitas yang sebelumnya telah dibuat. Setelah itu, jumlahkan seluruh aset yang ada dan lihat apakah hasilnya sudah sesuai (balance) dengan jumlah antara liabilitas dengan ekuitas.

\section{Prosedur Penyusunan Laporan Arus Kas}

Laporan arus kas terdiri dari tiga aktivitas, yaitu operasi, investasi, dan pendanaan. Hal pertama yang harus dilakukan adalah dengan menganalisa seluruh laporan keuangan yang telah dibuat sebelumnya. Setelah itu, posting seluruh perkiraan yang mempengaruhi perubahan kas perusahaan, baik dari aktivitas operasi, investasi, dan pendanaan. Di mana aktivitas operasi mencakup laba bersih, kenaikan atau penurunan mengenai utang, piutang, persediaan, beban bunga, serta beban depresiasi. Kemudian aktivitas investasi biasanya mencakup hal-hal terkait dengan aset tetap seperti peralatan, kendaraan, dan gedung. Sedangkan aktivitas pendanaan biasanya mencakup hal-hal terkait dengan penambahan modal, pembayaran dividen, pembayaran bunga, serta prive. 


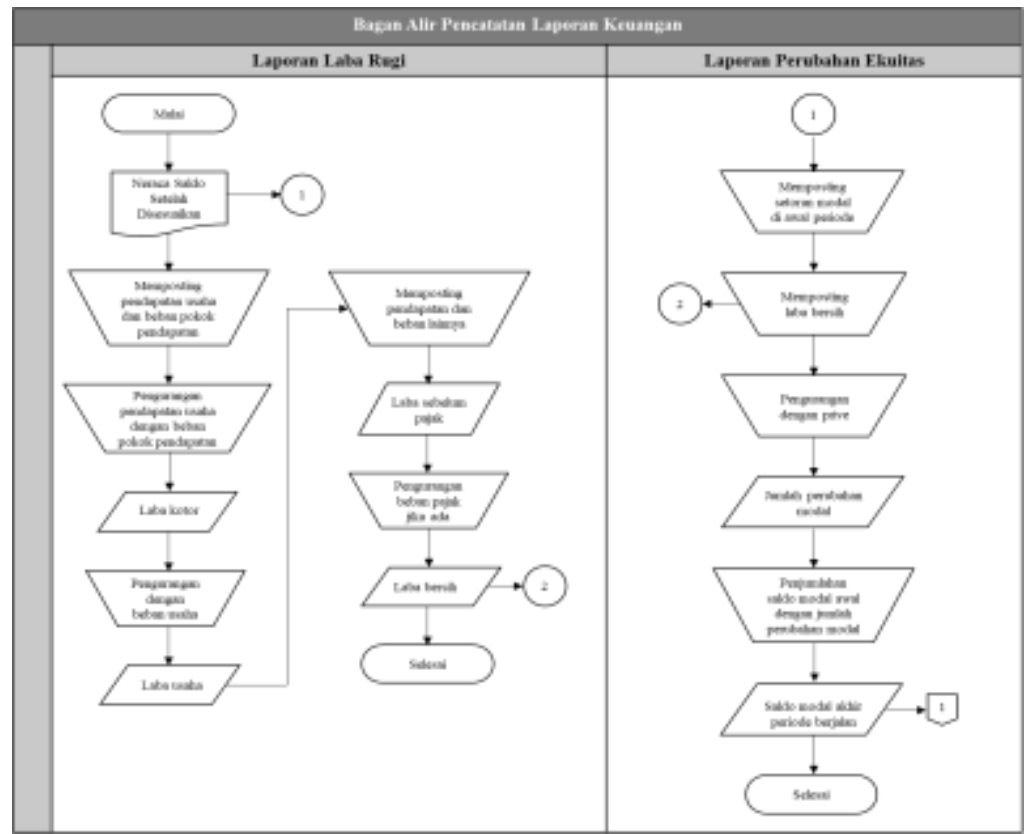

Gambar 7. Bagan Alir Pencatatan Laporan Keuangan

(Sumber: Bagan alir diolah oleh peneliti)

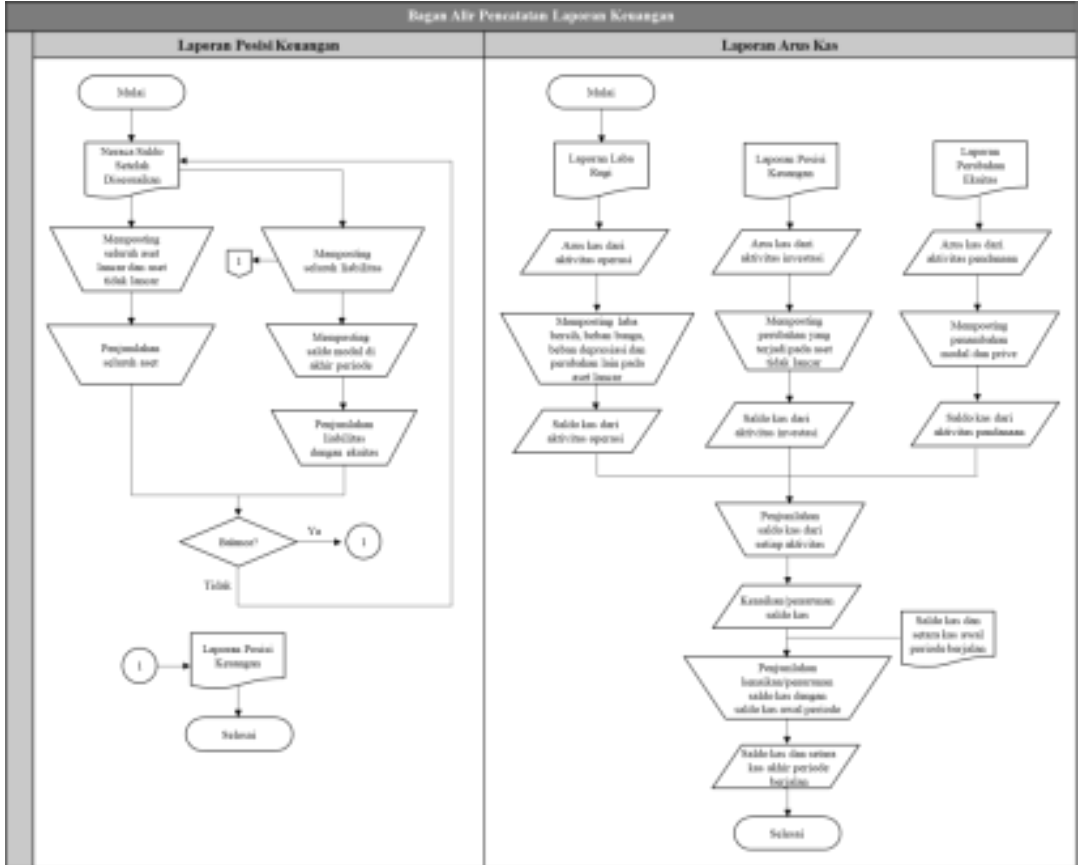

Gambar 8. Lanjutan Bagan Alir Pencatatan Laporan Keuangan (Sumber: Bagan alir diolah oleh peneliti)

\section{Bentuk Laporan Keuangan}

Dalam menjalankan kegiatan usaha, tentunya para pelaku UMKM harus membuat laporan keuangan, di antaranya seperti laporan laba rugi, laporan perubahan ekuitas, laporan 
posisi keuangan, dan laporan arus kas. Melalui laporan keuangan tersebut, para pelaku UMKM dapat mengetahui efektif atau tidaknya kegiatan usaha yang dijalankan. Selain itu, laporan keuangan juga digunakan sebagai pedoman dalam pengambilan keputusan, serta alat ukur kesehatan dan keberlanjutan usaha yang djalankan. Berikut merupakan bentuk-bentuk laporan keuangan:

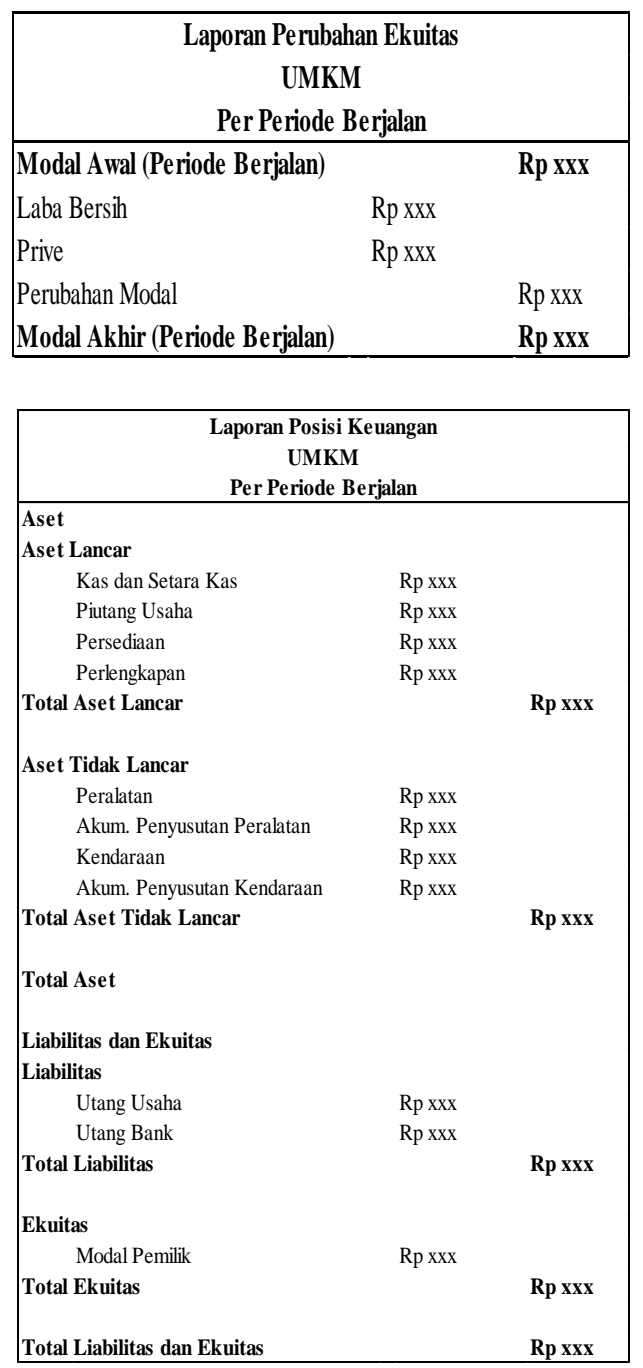

\begin{tabular}{|c|c|c|}
\hline \multicolumn{3}{|c|}{$\begin{array}{c}\text { Laporan Laba Rugi } \\
\text { UMKM } \\
\text { Per Periode Berjalan }\end{array}$} \\
\hline Pendapatan & $\operatorname{Rp} \times x x$ & \\
\hline Beban Pokok Pendapatan & $\operatorname{Rp} \times x x$ & \\
\hline Laba Bruto & & $\operatorname{Rp} x x x$ \\
\hline Beban Usaha & & $\operatorname{Rp} x x x$ \\
\hline Laba Usaha & & $\operatorname{Rp} x x x$ \\
\hline \multicolumn{3}{|c|}{ Pendapatan dan Beban Lainnya } \\
\hline Pendapatan Lain-Lain & $\operatorname{Rp} x x x$ & \\
\hline Beban Lain & $\operatorname{Rp} x x x$ & \\
\hline Laba Sebelum Pajak & & $\operatorname{Rp} x x x$ \\
\hline Laba Sebelum Pajak & $\operatorname{Rp} \times x x$ & \\
\hline *Beban Pajak & $\operatorname{Rp} x x x$ & \\
\hline Laba Bersih & & $\mathbf{R p} \times x x$ \\
\hline
\end{tabular}

\begin{tabular}{|c|c|c|}
\hline \multicolumn{3}{|c|}{$\begin{array}{c}\text { Laporan Arus Kas } \\
\text { UMKM } \\
\text { Per Periode Berjalan } \\
\end{array}$} \\
\hline \multicolumn{3}{|l|}{ Arus Kas dari Aktivitas Operasi } \\
\hline Laba Bersih & & Rp xxx \\
\hline Beban Bunga & $\operatorname{Rp} x x x$ & \\
\hline Beban Depresiasi & $\operatorname{Rp} x x x$ & \\
\hline Kenaikan/Penurunan Piutang Usaha & Rp xxx & \\
\hline Kenaikan/Penurunan Utang Usaha & $\operatorname{Rp} x x x$ & \\
\hline Kenaikan/Penurunan Persediaan & Rp xxx & Rp xxx \\
\hline $\begin{array}{l}\text { Arus Kas Bersih yang Diperoleh dari } \\
\text { Aktivitas Operasi }\end{array}$ & & $\mathbf{R p} \mathbf{x x x}$ \\
\hline \multicolumn{3}{|l|}{ Arus Kas dari Aktivitas Investasi } \\
\hline Peralatan & $\operatorname{Rp} x x x$ & \\
\hline Kendaraan & $\operatorname{Rp} x x x$ & \\
\hline $\begin{array}{l}\text { Arus Kas Bersih yang Diperoleh dari } \\
\text { Aktivitas Investasi }\end{array}$ & & Rp xxx \\
\hline \multicolumn{3}{|l|}{ Arus Kas dari Aktivitas Pendanaan } \\
\hline Penambahan Modal & $\operatorname{Rp} x x x$ & \\
\hline Prive & $\operatorname{Rp} x x$ & \\
\hline $\begin{array}{l}\text { Arus Kas Bersih yang Diperoleh dari } \\
\text { Aktivitas Pendanaan }\end{array}$ & & $\mathbf{R p} \mathbf{x x x}$ \\
\hline Kenaikan/Penurunan Kas Bersih & & $\operatorname{Rp} x x x$ \\
\hline Saldo Awal Kas (Periode Berjalan) & & $\operatorname{Rp} \mathbf{x x x}$ \\
\hline Saldo Akhir Kas (Periode Berjalan) & & $\mathbf{R p x x x}$ \\
\hline
\end{tabular}

Gambar 9. Laporan Keuangan (Sumber: Bentuk laporan keuangan diolah oleh peneliti)

\section{Software Pembukuan BukuKas}

Revolusi industri 4.0. menuntut para pelaku UMKM untuk dapat beradaptasi dengan segala perkembangan teknologi yang ada, termasuk dalam hal penggunaan software pembukuan akuntansi yang 
telah banyak tersedia secara gratis maupun berbayar. Kegiatan usaha yang dijalankan oleh para pelaku UMKM tentunya akan sangat efektif dan efisien jika menerapkan software pembukuan secara gratis. Pasalnya, software pembukuan tersebut dapat membantu para pelaku UMKM dalam mengelola seluruh kegiatan usaha yang dijalankan.

Berdasarkan hal tersebut, maka peneliti menyarankan para pelaku UMKM untuk menerapkan software pembukuan dalam menjalankan kegiatan usahanya. Software pembukuan tersebut ialah BukuKas, aplikasi pengelolaan keuangan digital gratis berbasis mobile untuk para pemilik usaha agar dapat mencatat transaksi penjualan, pengeluaran, dan hutang atau piutang secara lebih rinci tanpa harus menggunakan kertas dan pulpen. BukuKas dapat digunakan secara gratis dengan jumlah transaksi yang tidak terbatas. Para pemilik usaha dapat melihat dan mengunduh laporan transaksi berupa laporan keuangan dalam format PDF. Selain itu, BukuKas juga memiliki fitur untuk mengirim pengingat mengenai hutang atau piutang kepada para pelanggan melalui aplikasi WhatsApp dan media sosial lainnya.

Seluruh data yang telah diinput dalam BukuKas akan tersimpan dalam could server secara aman, sehingga para pemilik usaha dapat kembali mengakses akunnya walaupun menggunakan perangkat handphone yang berbeda. Para pemilik usaha hanya perlu login dengan menggunakan nomor yang sama. BukuKas dapat digunakan oleh para pemilik usaha dengan berbagai jenis usaha. BukuKas juga telah dipercaya dan digunakan oleh lebih dari 750.000 pelaku usaha mikro, kecil, dan makro di seluruh Indonesia. Dalam website resmi BukuKas tersebut telah tersedia pula berbagai fitur, kegunaan serta panduan untuk menggunakan aplikasi Buku Kas (bukukas.co.id). Berikut merupakan beberapa panduan untuk menggunakan aplikasi BukuKas:

1) Panduan Input Penjualan

Berikut adalah cara input transaksi penjualan di aplikasi keuangan BukuKas, di antaranya:

a. Buka aplikasi BukuKas.

b. Pada layar Transaksi, pilih Tambah Transaksi.

c. Kemudian pada kolom Penjualan Baru, masukkan nominal harga barang yang terjual dan harga pokok (jika ada). Keuntungan akan terkalkulasi secara otomatis.

d. Pilih status pembayaran, apabila Anda memilih "Belum Bayar," maka transaksi akan tercatat secara otomatis pada catatan Hutang.

e. Tambahkan keterangan lainnya (Catatan, Foto Bon, Metode Bayar, Tanggal, 
Status Pembayaran, Kontak, dan Detil Barang) jika diperlukan.

f. Klik Simpan.
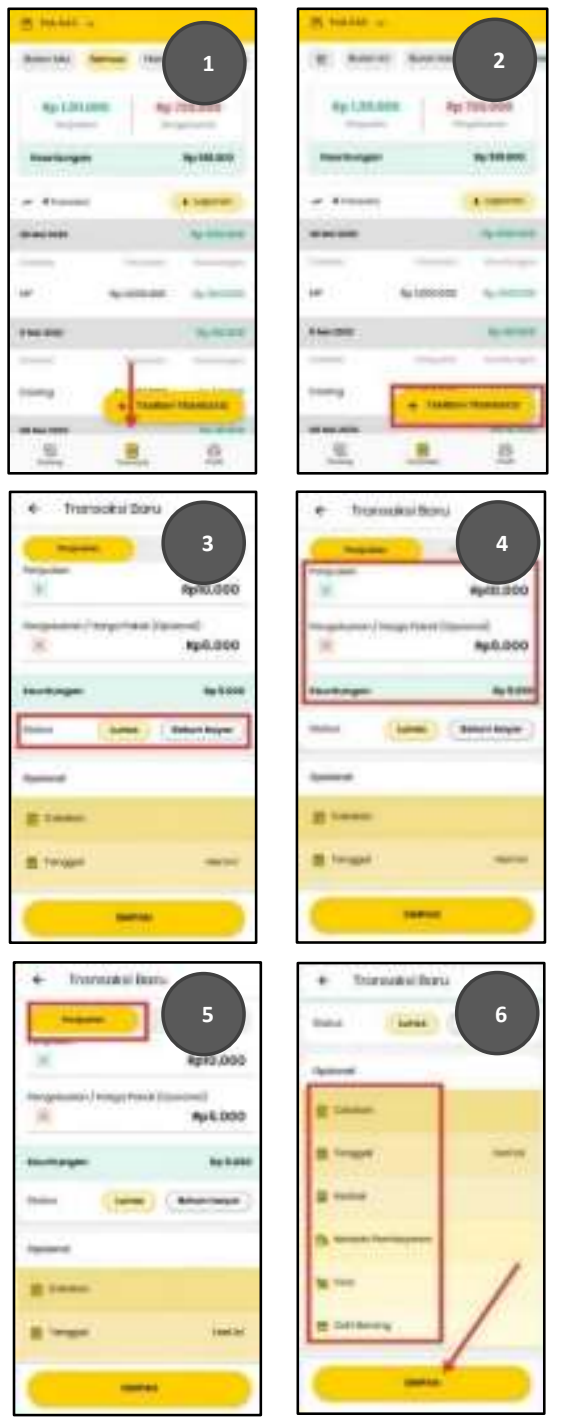

Gambar 10. Panduan Input Penjualan (Sumber: Aplikasi BukuKas)

2) Panduan Input Piutang

Berikut adalah cara input piutang pelanggan pada aplikasi pencatat keuangan BukuKas, di antaranya:

a. Buka aplikasi BukuKas.

b. Klik menu Hutang. c. Pilih kontak orang yang berhutang kepada Anda atau jika kontak belum ditambahkan, maka klik Tambah Kontak.

d. Masukkan nominal uang yang dihutangkan dengan klik Memberi dan isikan nominal uang yang dihutangkan. Tambahkan catatan, sesuaikan tanggal, dan pilih opsi pengingat otomatis di WhatsApp.

e. Klik Simpan.

f. Anda juga bisa menentukan tanggal jatuh tempo dari piutang tersebut.
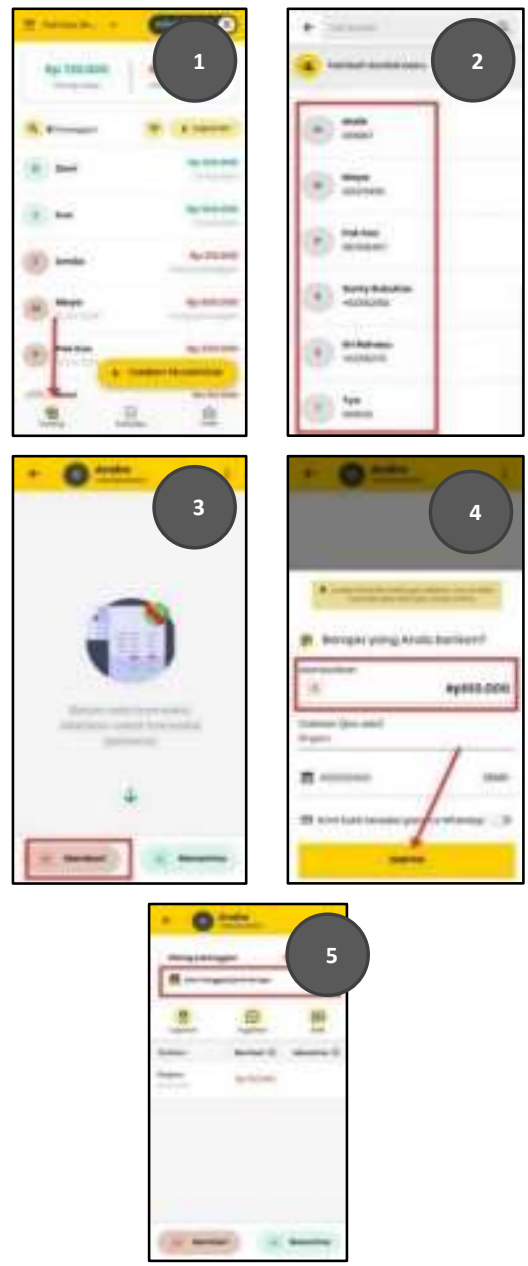
Gambar 11. Panduan Input Piutang (Sumber: Aplikasi BukuKas)

3) Panduan Input Pembayaran Piutang

Berikut adalah cara input pembayaran piutang pada aplikasi laporan keuangan BukuKas, di antaranya:

a. Buka aplikasi BukuKas.

b. Klik menu Hutang.

c. Pilih kontak orang yang membayar hutang.

d. Masukkan nominal uang yang dibayar dengan cara klik Menerima dan isikan nominal yang dibayarkan. Tambahkan keterangan (catatan, tanggal) jika diperlukan.

e. Klik Simpan.
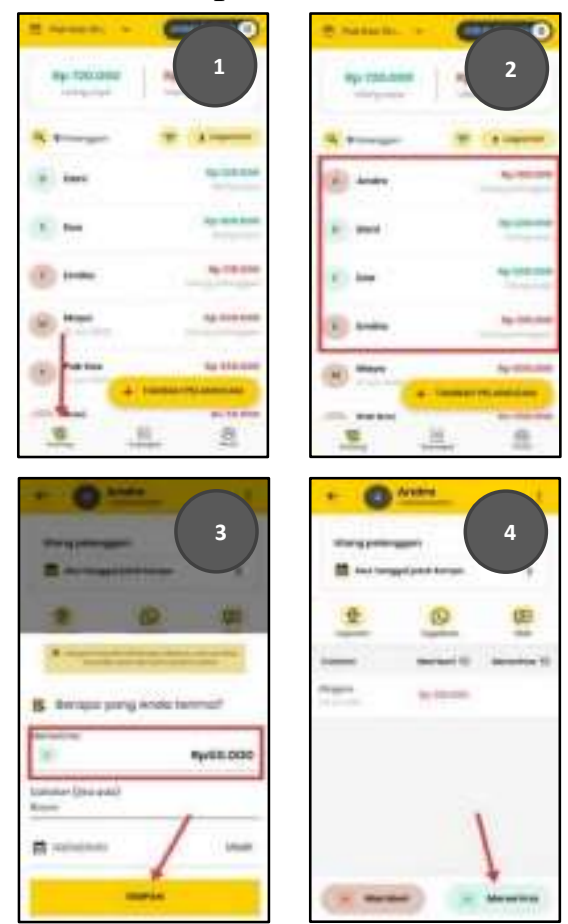

Gambar 12. Panduan Input

Pembayaran Piutang

(Sumber: Aplikasi BukuKas)
4) Panduan Unduh Laporan

Berikut adalah cara unduh laporan di aplikasi keuangan gratis BukuKas, di antaranya:

a. Buka aplikasi BukuKas pada menu Transaksi atau Hutang.

b. Sesuaikan tanggal laporan yang ingin diunduh dengan cara klik Ubah.

c. Pilih jenis laporan yang ingin kamu unduh (Laporan Laba Rugi/Laporan

Hutang Piutang/Laporan Pelanggan).

d. Pilih format laporan.

e. Klik Unduh dan laporan akan terunduh secara otomatis.
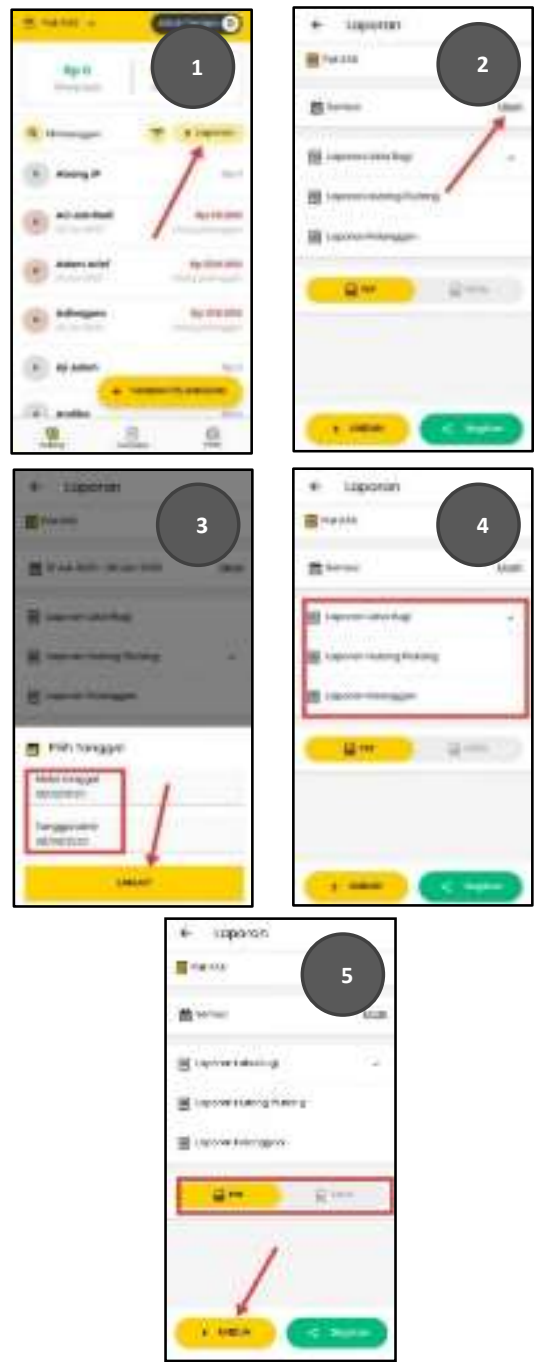
Gambar 13. Panduan Unduh Laporan (Sumber: Aplikasi BukuKas)

\section{KESIMPULAN}

Dalam menjalankan kegiatan usaha, pembukuan menjadi hal penting yang harus diterapkan oleh para pelaku UMKM. Pasalnya, pembukuan dapat membantu para pelaku UMKM untuk mengetahui untung atau tidaknya kegiatan usaha yang dijalankan. Pembukuan dapat dilakukan baik secara manual maupun komputerisasi.

Berdasarkan hasil penyebaran kuesioner, maka dapat diketahui bahwa delapan dari sepuluh pelaku UMKM masih menerapkan sistem pembukuan manual, di mana saat menerapkan sistem pembukuan manual tersebut masih terdapat beberapa permasalahan yang harus dihadapi oleh para pelaku UMKM tersebut, seperti lupa menyimpan bukti transaksi, kesalahan matematis saat berhitung, kesalahan pencatatan dan penyesuaian, serta lupa melakukan pencatatan. Oleh sebab itu, peneliti memberikan solusi bagi para pelaku UMKM untuk beralih dari sistem pembukuan manual ke sistem pembukuan komputerisasi atau dengan kata lain menerapkan software pembukuan akuntansi.

Software pembukuan akuntansi gratis yang mudah digunakan oleh para pelaku UMKM, salah satunya yaitu BukuKas, aplikasi pengelolaan keuangan digital gratis berbasis mobile yang telah dipercaya dan digunakan oleh lebih dari 750.000 pelaku usaha mikro, kecil, dan makro di seluruh Indonesia. Dengan menggunakan BukuKas, maka seluruh transaksi dapat dicatat tanpa adanya batasan sehingga para pelaku UMKM dapat dengan mudah melakukan pembukuan mengenai kegiatan usaha yang dijalankannya.

Melihat banyaknya manfaat yang diperoleh dari penerapan software pembukuan akuntansi, para pelaku UMKM diharapkan mulai menerapkan software pembukuan akuntansi guna mempermudah proses pembukuan dalam menjalankan kegiatan usaha.

Penelitian selanjutnya diharapkan mampu memaparkan lebih lengkap mengenai pola aktivitas akuntansi UMKM yang dikaitkan dengan fitur-fitur software pembukuan akuntansi agar dapat menjelaskan bagaimana pemanfaatan software akuntansi pada UMKM. Selain itu, penelitian selanjutnya juga diharapkan mampu mengembangkan dan memperluas responden sehingga hasil mengenai pemanfaatan software pembukuan akuntansi semakin akurat.

\section{DAFTAR PUSTAKA}

Arifin, M. Y., Indrianasari, N. T., \& Soemartono, S. (2018). "Analisis Sistem Informasi Akuntansi dalam Pengendalian Persediaan Barang Dagang pada PT. Kartini Teh Nasional Cabang Lumajang". Counting: 
Journal of Accounting, 1(2), 162-170.

Buku Kas-Aplikasi Pembukuan Keuangan Digital UMKM. Diakses pada 3 Juli 2020, dari https://www.bukukas.co.id/

Direktorat Jenderal Pajak. (2007). Undang-Undang Nomor 28 Tahun 2007. Diakses pada 29 Juni 2020, dari https://pajak.go.id/id/undangundang-nomor-28-tahun-2007

Fauziyah. (2020). "Tantangan UMKM dalam Menghadapi Revolusi Industri 4.0 Ditinjau dari Aspek Marketing dan Accounting". Jurnal Manajemen dan Kewirausahaan, 5 (2), 155172.

Hidayat, Anwar. (2017). Penjelasan Teknik Purposive Sampling Lengkap Detail. Diakses pada 2 Juli 2020, dari https://www.statistikian.com/2 017/06/penjelasan-teknikpurposive-sampling.html

Kementerian Koperasi dan Usaha Kecil dan Menengah Republik Indonesia. (2019). Kemkop dan UKM Targetkan Peningkatan Kontribusi UMKM Untuk PDB. Diakses pada 28 Juni 2020, dari http://www.depkop.go.id/read/ kemkop-dan-ukm-targetkanpeningkatan-kontribusiumkm-untuk-pdb

Krismiaji. (2015). Sistem Informasi Akuntansi (Edisi Keempat). Yogyakarta: Sekolah Tinggi Ilmu Manajemen YKPN.

Kurniawan, R., \& Diptyana, P. (2011). "Telaah Pemanfaatan Software Akuntansi oleh Usaha Kecil dan Menengah". The
Indonesian Accounting

Review, 1(2), 107-116.

Leski, Rizkinaswara. (2020).

Revolusi Industri 4.0. Diakses pada 28 Juni 2020, dari https://aptika.kominfo.go.id/20 20/01/revolusi-industri-4-0/

Mastura, M., Sumarni, M., \& Eliza, Z. (2019). "Peranan Infomasi Akuntansi terhadap Keberhasilan UMKM di Kota Langsa". Jurnal Ekonomi dan Bisnis Islam, 4(1), 20-33.

Media Digital. (2020). BukuKas, Solusi Pembukuan Keuangan Digital UMKM. Diakses pada 28 Juni 2020, dari https://ekonomi.bisnis.com/rea d/20200511/9/1238739/bukuka s-solusi-pembukuan-keuangandigital-umkm

Pangerapan, O. R. (2013). “Analisis Perlakuan Akuntansi Untuk Website pada PT. Bank Sulut (Persero) Manado". Jurnal EMBA: Jurnal Riset Ekonomi, Manajemen, Bisnis dan Akuntansi, 1(3).

Putra, Y. M. (2018). "Pemetaan Penerapan Standar Akuntansi Keuangan EMKM pada UMKM di Kota Tangerang Selatan". Profita, 11(2), 201217.

Rahardja, U., Aini, Q., \& Hardini, M. (2018). "Penerapan Software Akuntansi Online sebagai Penunjang Pencatatan Laporan

Keuangan”. Sisfotenika, 8(2), 176-187.

Rohman, Nur. (2019). Pengertian, Fungsi, Tujuan, dan Nilai Guna Arsip. Diakses pada 16 Juni 2020, dari https://akuntanonline.com/peng 
ertian-arsip-fungsi-dan-

tujuannya/

Solikah, Mar'atus., Astuti, Puji., Paramitha, Dyah Ayu. (2017).

"Analisis Faktor-Faktor yang Mempengaruhi Persepsi

Wirausahawan Terhadap

Pentingnya Pembukuan dan

Laporan Keuangan". Jurnal Akuntansi \& Ekonomi, 2 (1).

Sugiyono. (2010). Metode Penelitian

Kuantitatif Kualitatif dan $R \& D$. Bandung: Alfabeta.

Zahro, N. I., \& Whetyningtyas, A. (2017).

"Pemberdayaan

Masyarakat

Melalui

Pengelolaan Usaha UMKM

Cake \& Bakery di Desa Besito

Kecamatan Gebog Kabupaten

Kudus". In Seminar Nasional

Hasil Pengabdian Kepada

Masyarakat (SNHPKM)-VII

Lembaga Penelitian dan

Pengabdian Kepada

Masyarakat Universitas Pgri

Semarang. UPGRIS. 